\title{
Integrating Research, Undergraduate Education and Engineering Outreach
}

\author{
Kelsey E. Beach ${ }^{1}$ \\ Bachelor of Science in Mechanical Engineering, 2007 \\ Paul M. Boyle ${ }^{1}$ \\ Bachelor of Science in Mechanical Engineering, 2007 \\ Clint C. Corcoran ${ }^{1}$ \\ Bachelor of Science in Mechanical Engineering, 2007
}

Ali N. Hamshari ${ }^{1}$

Bachelor of Science in Mechanical Engineering, 2007

James J. Tuttle ${ }^{1}$

Bachelor of Science in Mechanical Engineering, 2007

David M. McStravick ${ }^{1}$

Professor in the Practice

Brent C. Houchens ${ }^{1}$

Assistant Professor

houchens@rice.edu

${ }^{1}$ Department of Mechanical Engineering and Materials Science

6100 Main Street, Rice University, MS-321

Houston, TX 77005

Abstract - A capstone design project targeted at engineering outreach to grade school students in both developed and developing countries was designed and constructed. The resulting Adaptive WaTER (Water Treatment for Education and Research) Laboratory teaches students about water filtration and sterilization through hands-on procedures, and encourages sustainable water practices through education. The Laboratory relies almost entirely on human power, with one optional module running on batteries, which can be recharged via a solar backpack. Therefore no infrastructure is required to take full advantage of the Laboratory. The team presented the Laboratory to over $\mathbf{3 0 0}$ grade school students in the Houston area through interactive demonstrations, and developed Laboratory procedures for widespread dissemination of the Laboratory to schools. The nonprofit Schlumberger Excellence in Educational Development (SEED) Foundation is now determining the feasibility of scaling-up production of the prototype Laboratory for donation to some or all of the nearly 200 schools they support in the developing world. The design team also submitted a proposal to the Environmental Protection Agency and was awarded a P3: People, Prosperity and the Planet Student Design Competition for Sustainability grant. Finally, the practical knowledge gained about water filtration directly aided a new research collaboration on understanding and preventing fouling of reverse osmosis membranes.

Index Terms - capstone design, education, outreach, service 


\section{INTRODUCTION}

During the summer of 2006 a senior capstone design project to investigate water treatment in the absence of an external power supply was proposed by Drs. McStravick and Houchens. This project was inspired both by the scarcity of potable water in New Orleans following Hurricane Katrina and with an outlook to future educational outreach and research on sustainable water practices. Schlumberger Oilfield Services saw an opportunity to implement this project through their nonprofit Schlumberger Excellence in Educational Development (SEED) Foundation'. This foundation encourages grade school science and mathematics education in the developing world, with a focus on sustainability. The nearly 200 current SEED schools are supplied with computers, power, heating, ventilation and air-conditioning, internet service and various educational kits. For instance, the SEED Water Project ${ }^{\mathrm{ii}}$ kit comes with supplies for collecting and testing water from local sources. Students perform the experiments and post results on a website viewable by all other SEED school students. The capstone project was seen as a natural extension of the SEED Water Project and the collaboration formed with five senior Rice University mechanical engineering students adopting the project for the year long course. The result of this project is the Adaptive WaTER (Water Treatment for Education and Research) Laboratory (referred to as the Laboratory below).

\section{DESign Challenge}

The Adaptive WaTER Laboratory will be used in a kit as part of the SEED Water Project. A kit is a set of five student solar backpacks like that shown in Figure 1 and one slightly larger teacher backpack. The kit contains the necessary experimental materials and documentation as well as educational information, all typically packaged in the backpacks.

Designing the system to be a SEED kit necessitated the following constraints. The design had to be small, lightweight, and portable to fit into the six backpacks. The total cost of the kit was limited to $\$ 1000$, including a suitable number of replacement materials, consumables and component backups to last through at least one year of heavy use, with minimized disposables. The system could not rely on electrical infrastructure, as the kit may be used in the field or in areas of the world lacking a reliable (or any) source of electricity. The SEED solar backpacks

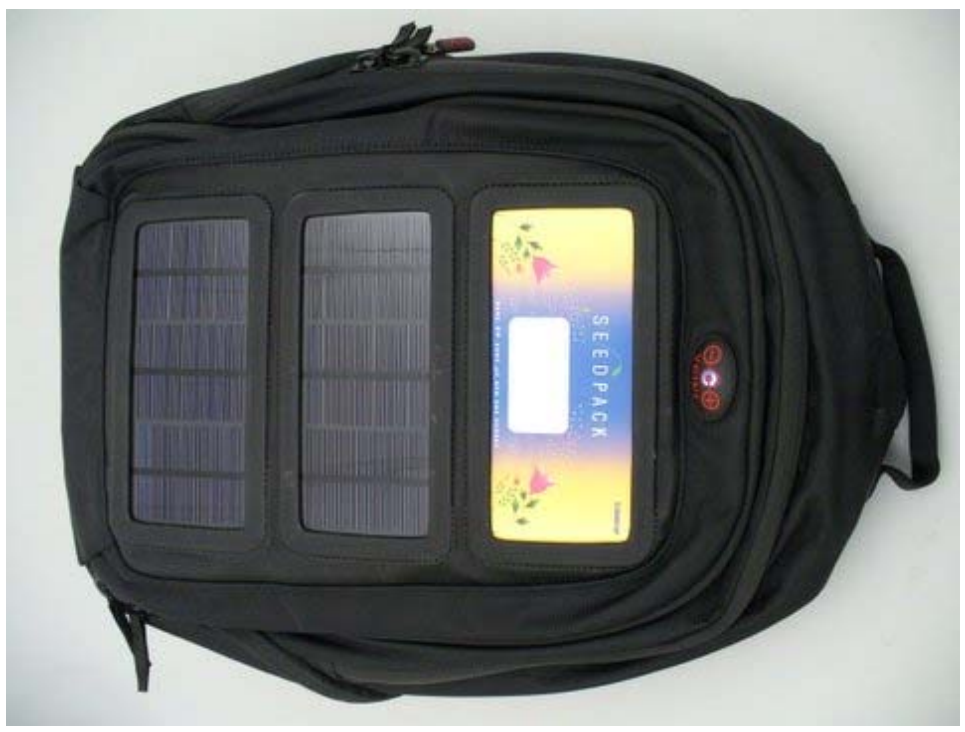

FIGURE 1

SEED SOLAR BACKPACK (SEEDPACK) SHOWN WITH ONE SOLAR PANEL REMOVED. 
(SEEDPACKs ${ }^{\mathrm{iii}}$ ) have three solar panels, each capable of producing a peak power of 1.5 watts. Together the panels can recharge batteries or power small devices; otherwise the system was required to be human-powered. Finally, and most importantly, the system had to be educational, interactive, easy to use, and appealing to multiple age groups and cultures. The primary focus was placed on education and hands-on experiments rather than the production of a significant volume of drinking water (which is addressed in an EPA P3: People, Prosperity and the Planet Student Design Competition for Sustainability grant discussed in the Future Work section).

An additional goal was to discuss a variety of purification methods and the different combinations of those methods. This would emphasize what methods work effectively together as opposed to individually, and that multiple combinations of methods could accomplish similar purposes with various power and time limitations. By introducing students to the spectrum of water treatment technology, the Laboratory would provide a range of solutions to be optimized for sustainability in the various regions of the world it serves. Hence, the Laboratory needed interchangeable components and experimental procedures that compared different combinations of methods. All of these requirements were accomplished, allowing the Laboratory to teach countless students in schools throughout SEED's international network. Simultaneously, this project helped develop intuition and a foundation for later use in fundamental research on reverse osmosis membrane filtration.

\section{TEChNiCAL DESIGN AND EVALUATION}

The Adaptive WaTER Laboratory was developed and constructed to meet the design requirements discussed above. Six distinct housings each contain a different purification method, and the housings can be attached to one another in different orders to achieve multiple water purification solutions. The housings create a watertight environment that can be easily cleaned and pressurized as needed with a pressure cap and hand pump. Water is poured into the top of the stackable housings and dispensed at the bottom into outlet cups.

The methods selected filter or destroy common waterborne health threats. A sediment filter removes large contaminants such as dirt. A carbon filter removes slightly smaller contaminants as well as some chemicals. Chemical and ultraviolet (UV) light disinfection kill or neutralize biological contaminants, namely bacteria and viruses. A reverse osmosis (RO) membrane traps contaminants as small as pieces of viruses. A forward osmosis (FO) membrane is not part of the stackable experiments, as it works independently to extract clean water from highly contaminated water. The multiple filtration and sterilization stages of the Laboratory educate students on the purpose of each individual method as well as the necessity of combining methods to eliminate all waterborne threats.

The housings are built primarily out of 4-inch PVC and clear acrylic. Straight PVC and acrylic pipe, PVC bar stock, and prefabricated PVC fittings were machined in the Rice University machine shop for compatibility with the various filters and components. Malethreaded and female-threaded PVC fittings are used to attach one housing to the next. Adapting standard parts allows for easy and cheap fabrication and good reproducibility. With housings that screw together, the possible combinations of the Laboratory experiments are greatly increased. Furthermore, both effective and ineffective combinations can be explored through trial and error by the students. This concept also allows for the Laboratory to be easily split up among the backpacks and promotes collaboration between students by requiring several housings in each experimental assembly. The designs of each housing section are described below, followed by an evaluation of the effectiveness of each method on removing or neutralizing various contaminants. All filters are available commercially. 


\section{Sediment and Carbon Filtration}

The most basic water filtration techniques include sediment and carbon filtration. The sediment and carbon filters have nearly identical housings built in two halves, as shown in Figure 2. The top half screws onto the bottom half using male to female pipe connectors. An approximately 5inch filter is set between the two halves, and rubber gaskets create a watertight seal between the filter and PVC when the two halves are screwed together.

The sediment filter removes large debris such as silt, clay, colloids, and many types of microorganisms. ${ }^{\text {iv }}$ The filter selected for this project has a 5 micron rating such that $99.9 \%$ of particles larger than the nominal rating will not pass through the filter pores. ${ }^{\mathrm{V}}$ Sediment filtration is a necessary pre-filter for most of the water purification experiments in the Laboratory. Applying a sediment filter reduces the possibility of clogging later stage filters with smaller micron ratings and renders methods such as ultraviolet light more effective by reducing the opacity of the water due to suspended particles (turbidity).

The activated carbon filter removes some chemicals, heavy metals, and organic compounds. ${ }^{\mathrm{vi}}$ It also improves taste and odor. The carbon filter has a 0.5 micron rating, acting as a second sediment filter to remove additional particulate matter. A block carbon filter was selected over granular carbon suspended in cellulose for two reasons: the cellulose filter is susceptible to bacterial degradation, and a carbon block filter has a smaller micron rating.

These two methods are the most inexpensive, durable and effective from both a performance and educational perspective. The sediment and carbon filters cost approximately \$3 and \$7, respectively. They can filter roughly 3,000 gallons of water (depending on initial contamination levels), which more than satisfies the requirements for this project. Both processes are very fast, requiring less than a minute when pressurized with a hand pump. Furthermore, the results are highly visual. Both filters significantly reduce turbidity, an immediate effect that students can see and understand, yet the importance of further purification is easily shown with a coliform bacteria test. To highlight the visual nature of these components, a semi-transparent PVC housing was constructed for the carbon filter, as shown in a demonstration in Figure 7.

When combined with an intermediate chemical treatment step, these filtration methods represent the simplest and cheapest means of producing potable water. Pumping water through this system with a hand or foot pump quickly produces sufficient water for human survival. Again, this series of methods works well in the classroom. Students can see the removal of heavy contaminants after sediment filtering, observe the chemical tablet dissolve and smell the resulting odor, and finally achieve clear and odorless water after carbon filtration.
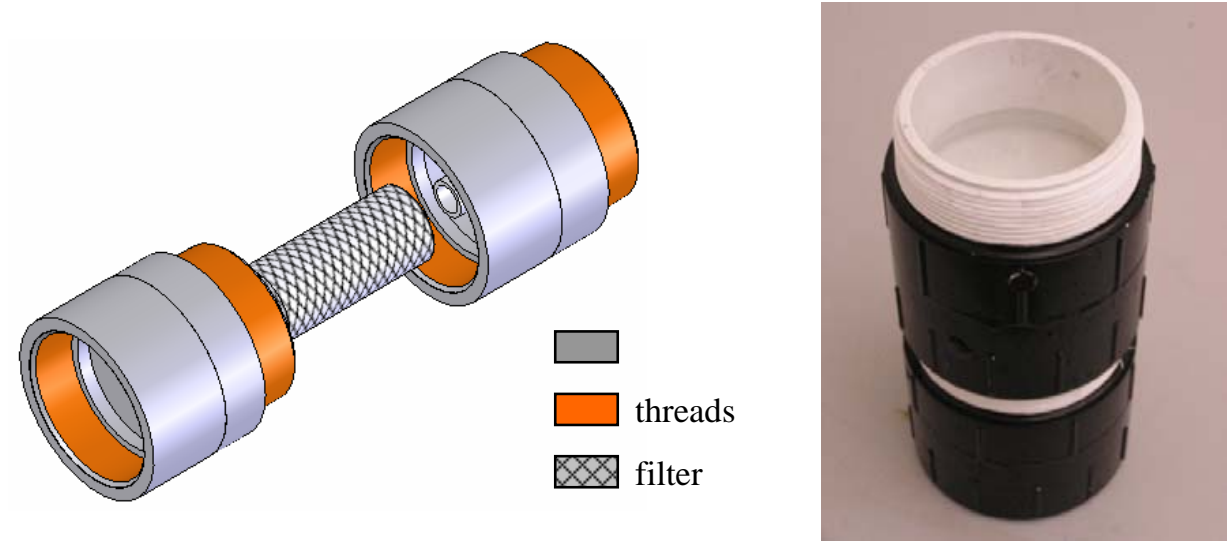

FIGURE 2

SOLIDWORKS MODEL AND PROTOTYPE OF THE SEDIMENT AND CARBON HOUSING AND FILTER. 


\section{Forward and Reverse Osmosis}

Advanced purification techniques include Forward Osmosis (FO) and Reverse Osmosis (RO) filtration. While they work on similar principles, the interesting educational aspects of these separation techniques are the significant differences in membrane costs, longevity and power consumption.

The FO housing is simply a female-threaded cap screwed onto a male threaded cup as shown in Figure 3a. Attached to the cap is the LifePack, ${ }^{\text {vii }}$ an FO membrane of extremely small pore size in the shape of a bag. The cup is filled with contaminated water and the bag lowered into it. A sugar syrup is placed on the interior of the bag. The concentration gradient between the syrup solution inside the membrane and the brackish water outside the membrane causes water to be drawn into the interior of the bag. No power is required, but the process is relatively slow, requiring approximately four hours to filter one liter of water.

The FO system is a one-step solution requiring no pre-filtration. Due to the simplicity of an FO experiment, background information and school demonstrations emphasize the disadvantages of FO in contrast to other more complicated but more affordable systems. First, FO membranes are expensive, ranging from $\$ 35$ to $\$ 75$ for this bag configuration. Second, the membrane has a limited lifespan: the LifePack has a projected ten-day lifetime, although tests have shown it can be used somewhat beyond that length of time. The FO laboratory experiments, then, emphasize the importance of looking at multiple purification solutions to find that which is most applicable in a given situation. For instance, a sediment, chemical, and carbon system is a more appropriate long-term solution, whereas FO is well-suited for disaster relief.

RO works by a pressure gradient as opposed to a concentration gradient. Whereas in FO clean water is drawn across the membrane leaving contaminants outside, in RO clean water is pushed through tiny pores, trapping contaminants in the semi-permeable membrane. ${ }^{\text {viii }}$ RO membranes may have pore sizes ranging from 0.0001 to 5 microns. A 0.0009 micron membrane was used in this project. This pore size is small enough to prevent even parts of viruses from passing through the membrane, ensuring that the extracted water is free of pathogens. ${ }^{\text {ix }}$ This small pore size necessitates a large pressure gradient. A pressure gradient of 50 pounds per square inch gauge (psig) between the brackish and clean water sides is developed to force water through the RO membrane, without causing damage to the PVC housing. This gradient can be achieved with a hand or foot pump, but the resulting flow rate is slow (several drops per minute).
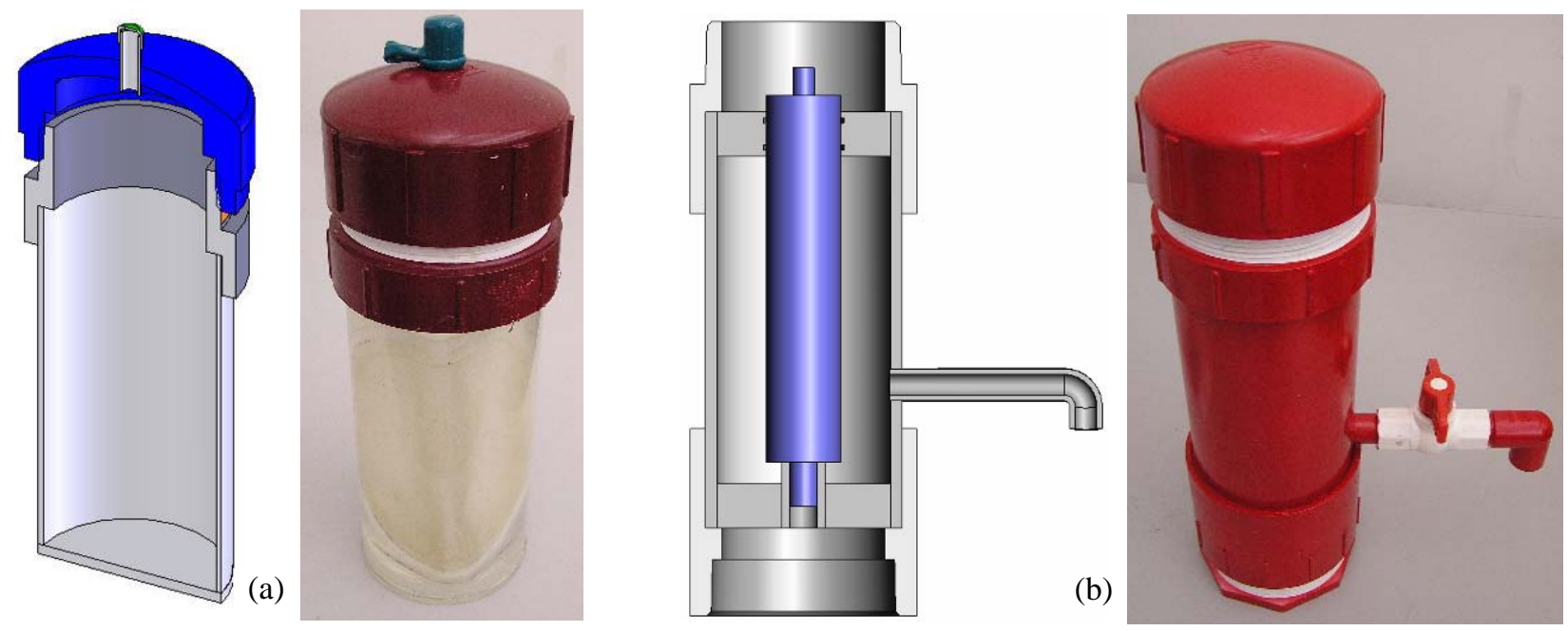

FIGURE 3

SOLIDWORKS MODELS AND PROTOTYPES OF THE (a) FO AND (b) RO HOUSINGS AND FILTERS. 
The RO housing encloses a 10-inch RO membrane as shown in Figure 3b. Machined PVC bar stock and o-rings stabilize the RO membrane by securing its distinctly-shaped ends. The housing is also designed to accommodate axial flow: contaminated water flows axially along the membrane and clean water is pushed radially to the interior of the membrane. The RO housing has an outlet valve to drain the water that has not been purified, a solution called "brine." The valve is closed during experiments to achieve pressurization.

One final design issue that had to be taken into account was that the RO membrane must remain moist and sterile in order to be effective. To maintain a clean, damp environment, the RO housing can be transformed from its functional state into a storage container by screwing a male-threaded plug onto the bottom of the housing and a female-threaded cap onto the top of the housing. Keeping the RO membrane moist allows it to be used for multiple experiments and up to several thousand gallons over the lifespan of the filter.

\section{Chemical and UV Sterilization}

Sterilization techniques capable of killing both bacteria and viruses include chemical treatment and ultraviolet (UV) sterilization. Both methods introduce potential hazards to students, requiring careful instructions, close monitoring by instructors and mistake-proof designs.

Chemical treatments destroy or inactivate pathogens. For bacteria and other microorganisms, chemicals either rupture the cell wall or diffuse through the cell wall and cause the pathogen to disintegrate from the inside out. Chemicals may also break bonds, prevent protein production, or destroy a cell's membrane or virus's protective shell. ${ }^{\mathrm{x}}$ For this project, chlorine dioxide is used because it is effective in small doses, is inexpensive and readily available, and has no risk of allergic reaction.

A commercially available chemical tablet called Potable Aqua ${ }^{\circledR}$ is added to one liter of water. This tablet kills or renders inert bacteria and viruses in approximately twenty minutes, some parasites within thirty minutes, and highly resilient parasites such as cryptosporidium parvum in four hours.

Due to the length of time necessary to eliminate all threats as well as the simplicity of adding the chemical tablet, a separate housing for this method was not constructed. Instead, water is deposited into a threaded outlet cup, a chemical tablet is added, and then the cup is set aside for the full wait time. The advantage of using a cup as opposed to a stackable housing with an outlet hole at the bottom is that students can set aside the cup without risk of leakage and perform other experiments as the chemical tablet slowly disinfects the water.

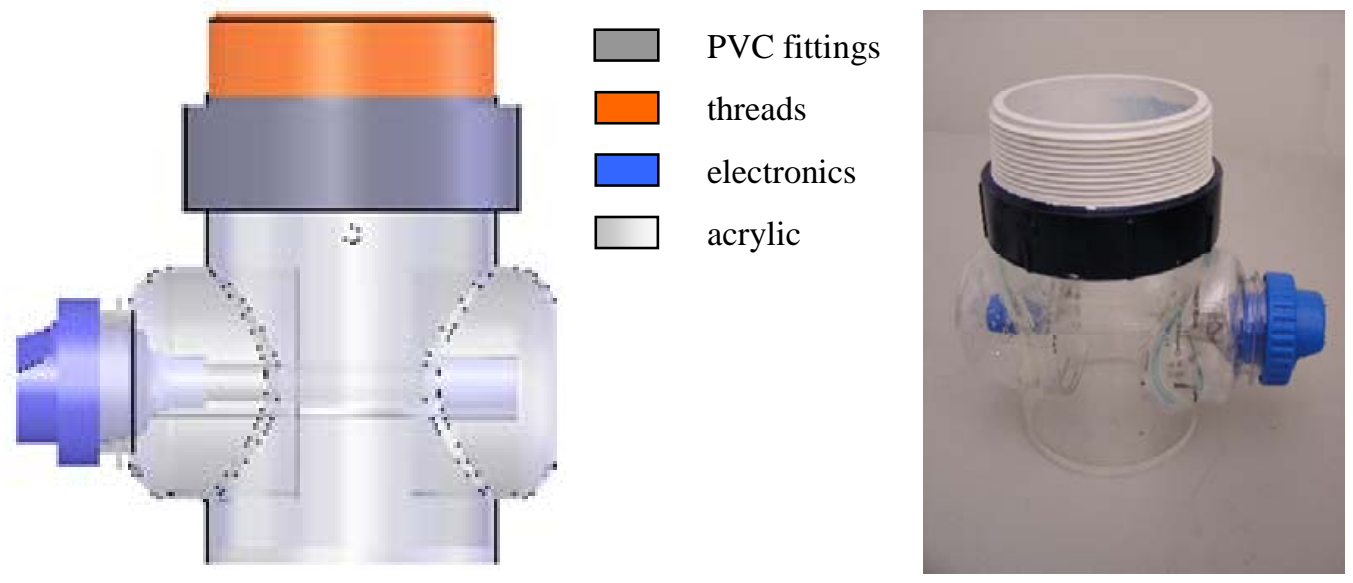

FIGURE 4

SOLIDWORKS MODEL AND PROTOTYPE OF THE UV STERILIZATION HOUSING AND BULB. 
In UV sterilization, water is exposed to a UV bulb, and pathogens absorb the harmful radiation. UV radiation damages pathogens' DNA or RNA, preventing them from passing on diseases. Germicidal light (UV-C) is used for this purpose and has a wavelength between 200 and $300 \mathrm{~nm}$. Although wavelengths of 260-265 nm are most effective, most UV sterilizing bulbs - including the one used in this project - act at $253.7 \mathrm{~nm}$ due to the relative ease of producing radiation at that wavelength. ${ }^{\mathrm{xi}}$

The UV housing shown in Figure 4 uses the electronics from Meridian Design's AquaStar ${ }^{\mathrm{TM}}$ Plus! UV Water Treatment Device. ${ }^{\text {xi }}$ The AquaStar is similar to a Nalgene drinking water bottle. The electronics and UV bulb are integrated into a cap, and the cap is screwed onto the top of the bottle, lowering the bulb into the water. To accommodate our stackable design, the electronics were mounted into the side of our basic cup design. This placement allows other housings to be screwed on top of the UV housing. The cap is now screwed into the side of the cup, creating a watertight seal and allowing for easy replacement of the bulb if it breaks or burns out. The housing design ensures student safety. UV-C light is blocked by most materials including the acrylic and PVC used in the housing, and in fact cannot pass through a water/air interface. As long as the system is used properly, i.e. the bulb is only turned on when installed in the assembly, there is no risk of exposure to UV.

In use, the housing is filled with 1 liter of water, although between $0.9 \mathrm{~L}$ and $1.3 \mathrm{~L}$ can be effectively sterilized. The AquaStar is intended to run for 80 seconds. Tests described below showed a small presence of bacteria following this dose when the initial sample was highly contaminated. Therefore laboratory procedures advise a double dose of 160 seconds to eliminate all pathogens. Automatic shutoff conserves battery life, reduces the possibility of user error, and prevents accidental exposure to the light. The AquaStar runs on two rechargeable CR123A lithium ion batteries; the batteries can be recharged using the solar panels on the SEEDPACK.

Each backpack carries one treatment method. UV bulbs and chemical tablets are stored in the teacher backpack due to the potential dangers of radiation exposure and chemical ingestion.

\section{Evaluation}

The Rice Chapter of Engineers Without Borders offered equipment for bacterial testing ${ }^{\text {xiii }}$. IDEXX Colisure and E. Coli tests were performed on the various treatment methods to determine their effectiveness at eliminating coliform bacteria and E. Coli. ${ }^{\text {iv }}$ A $100 \mathrm{~mL}$ sample
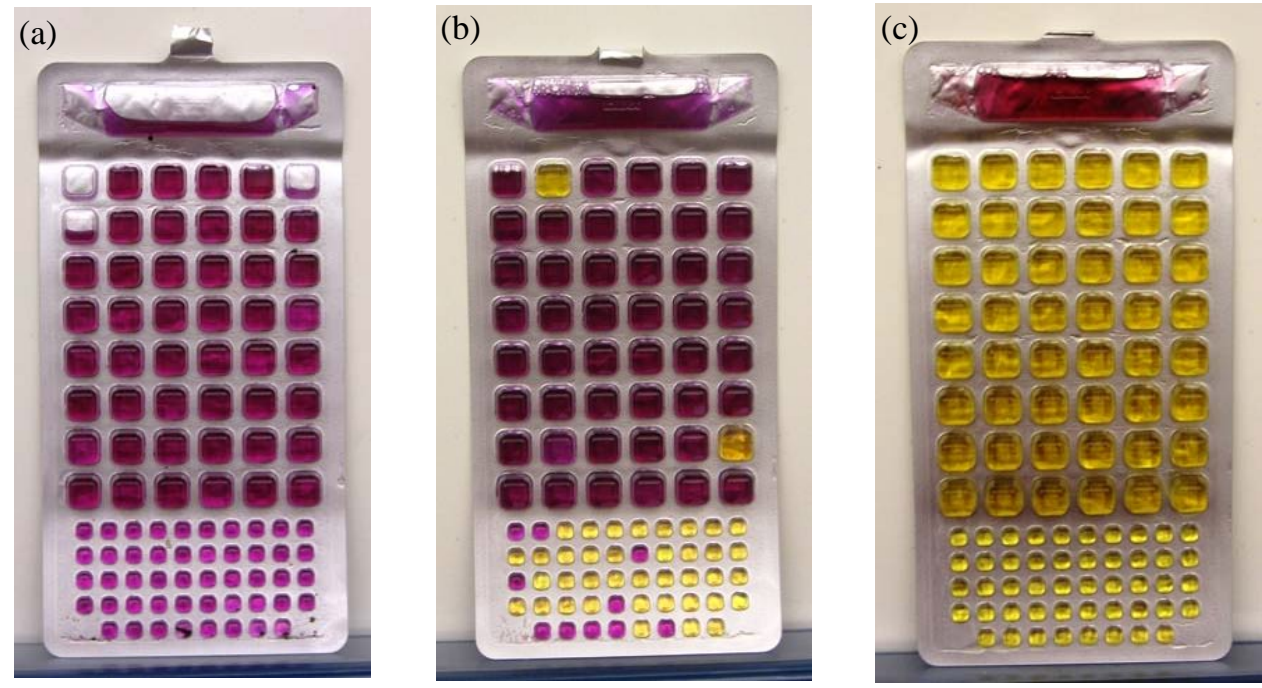

FIGURE 5

RESULTS OF BACTERIA TESTING AFTER VARIOUS FILTRATION/STERILZATION TECHNIQUES. 
of water was mixed with a Colisure reagent and then poured into a Quanti-Tray®, shown in Figure 5. The Quanti-Tray ${ }^{\circledR}$ holds the water sample in 97 wells of three sizes. The trays are incubated at $34^{\circ} \mathrm{C}$ for 24 hours. An algorithm calculates the total number of coliforms from the number of cells that change color from yellow to purple. The maximum Most Probable Number (MPN) of coliforms per mL that can be determined from the test is $2419 \mathrm{MPN} / \mathrm{mL}$. Yellow cells indicate less than 1.0 MPN/mL, or a 99.9\% removal effectiveness. The control sample (a) shows contaminated water from Braes Bayou in Houston, TX before any treatment. In this case all cells have turned purple, indicating that the total $\mathrm{MPN} / \mathrm{mL}$ is at least 2419, and may be considerably higher. The presence of $E$. Coli is determined by shining a black light or UVA light on the Quanti-Tray ${ }^{\circledR}$. The number of wells that fluoresce indicates the amount of E. Coli. ${ }^{\mathrm{xv}}$ The Braes Bayou water also showed the maximum level of E. Coli contamination measurable.

The chemical, FO, RO, and UV methods are all designed to eliminate the risk of coliform bacteria and E. Coli. Sediment and carbon filters are necessary pre-filters for UV sterilization. The sediment and carbon filters do not eliminate bacteria, as is shown in Table I, but they do sufficiently reduce the turbidity for effective UV sterilization. Again, all methods were tested on water collected from Braes Bayou, a highly contaminated water source. Control experiments were conducted on tap water and unfiltered Braes Bayou water. The tap water is a control for a negative bacteria test, and the bayou water is a control for a positive bacteria test.

As shown in the Table I, most of the technologies performed according to expectations. The sediment and carbon filters, which do not remove bacteria, showed the maximum possible $\mathrm{MPN} / \mathrm{mL}$ of both coliform bacteria and E. Coli. Two FO products were tested. Both the XPack $^{\mathrm{Xvi}}$ and the LifePack eliminated all bacteria. Two UV products were also tested. The

TABLE I

BACTERIA TEST RESULTS (PERFORMED ON BRAES BAYOU WATER UNLESS OTHERWISE NOTED).

\begin{tabular}{|c|c|c|c|c|c|}
\hline \multirow{2}{*}{ Sample } & \multirow{2}{*}{ Pre-filters } & \multicolumn{2}{|c|}{ Total Coliforms } & \multicolumn{2}{|c|}{ E. Coli } \\
\hline & & $(\mathrm{MPN} / \mathrm{mL})$ & \% removal & $(\mathrm{MPN} / \mathrm{mL})$ & \% removal \\
\hline tap water (control) & none & $<1.0$ & $\mathrm{~N} / \mathrm{A}$ & $<1.0$ & N/A \\
\hline Braes Bayou water (control) & none & $2419+$ & $\mathrm{N} / \mathrm{A}$ & $2419+$ & N/A \\
\hline sediment & none & $2419+$ & $0 \%$ & $2419+$ & $0 \%$ \\
\hline carbon & none & $2419+$ & $0 \%$ & $2419+$ & $0 \%$ \\
\hline chemical (4 hours) & sediment \& carbon & 2 & $99.9 \%$ & $<1.0$ & $99.9 \%$ \\
\hline FO - X-Pack (14 days) & none & $<1.0$ & $99.9 \%$ & $<1.0$ & $99.9 \%$ \\
\hline FO - LifePack (1 day) & none & $<1.0$ & $99.9 \%$ & $<1.0$ & $99.9 \%$ \\
\hline UV - SteriPen (90-sec. dose) & none & $2419+$ & $0 \%$ & 2419 & $0 \%$ \\
\hline UV - SteriPen (45-sec. dose) & sediment \& carbon & $2419+$ & $0 \%$ & 248.9 & $89.7 \%$ \\
\hline UV - SteriPen (180-sec. dose) & sediment \& carbon & 52.9 & $97.8 \%$ & 4.1 & $99.8 \%$ \\
\hline UV - AquaStar (80-sec. dose) & sediment \& carbon & 146.7 & $93.9 \%$ & N/A & N/A \\
\hline UV - AquaStar (160-sec. dose) & sediment \& carbon & $<1.0$ & $99.9 \%$ & $\mathrm{~N} / \mathrm{A}$ & N/A \\
\hline $\mathrm{RO}$ & sediment \& carbon & $<1.0$ & $99.9 \%$ & N/A & N/A \\
\hline
\end{tabular}


SteriPen $^{\text {xvii }}$ is designed to purify $1 \mathrm{~L}$ of water in 90 seconds. A half dose of 45 seconds did not eliminate the bacteria, as was expected. However, a double dose of 180 seconds reduced the coliform bacteria by $97.8 \%$ and $E$. Coli by $99.8 \%$, impressive levels given the highly contaminated nature of the initial sample. The second UV product, the AquaStar, was implemented in the UV sterilization housing due to its electronics configuration, which was more conducive to the design. The AquaStar also performed exceptionally well in bacteria tests. The AquaStar is designed to purify $1 \mathrm{~L}$ of water in 80 seconds. However, we tested the AquaStar in the final housing, when the total amount of water was approximately $1.2 \mathrm{~L}$. A single dose of UV light - 80 seconds - eliminated 93.9\% of the bacteria as shown in Figure 5b. It should be noted that the smaller cells in the Quanti-Trays ${ }^{\circledR}$ are weighted heavily in the calculation of bacterial presence. Two doses of UV light - 160 seconds - eliminated 99.9\% as shown in Figure 5c. Note that for two doses of UV light, the cell at the top of the Quanti-Tray® was yellow when the test was first run but turned purple several days later. This effect suggests that either there was a small amount of bacteria present or more likely that the test was re-contaminated. The RO membrane was also tested after a sediment and carbon pre-filter. This method eliminated 99.9\% of the coliforms, as expected. E. Coli tests were not conducted on either the final UV prototype or the RO prototype due to a loss of availability of the testing equipment.

SEED currently distributes a kit with materials for testing water quality in the Water Project. The kit includes $\mathrm{pH}$, chlorine, bacteria, and heavy metal tests. Students will use these kits to test the water at the beginning and end of the various Laboratory experiments in order to understand what contaminants are being removed. For bacteria testing, a nutrient tablet is added to a $10-\mathrm{mL}$ sample of water, and like the previously described test, the resulting mixture fosters the growth of bacteria. The test is not quantitative: it merely indicates the presence or absence of bacteria. Bacteria are present if the mixture is yellow, and foam -generated during the test- floats to the surface of the water. The test is negative if the mixture is red and the foam remains at the bottom of the bottle.

This test was only conducted on one purification method, the FO X-Pack, with water that had been contaminated with dirt. The X-Pack is designed to last 10 days. A test was conducted on the purified water one day after use and six days after use (half the total life). Both tests were negative for bacteria. We also conducted a control test on tap water (negative for bacteria) and a control test on water contaminated with dirt and fecal matter (positive). The latter tests were performed in order to demonstrate the testing capabilities to students at the Sally Ride engineering festival at Rice University.

\section{EDUCATIONAL OUTREACH}

With a focus on education, partnerships with local Houston-area schools and the Society of Women Engineers facilitated the presentation of the Adaptive WaTER Laboratory to over 300 grade school, middle school and high school students in Houston area public schools (Alief Independent School District ${ }^{\text {xviii }}$, Houston Independent School District - HISD $^{\text {xix }}$, and Klein Independent School District ${ }^{\mathrm{xx}}$ ). The students were predominately from underrepresented groups. The number of students served by school is presented in Table II, including student demographics based on 2005-2006 data. Numbers served refer to the size of the group for each presentation. Outreach efforts served a large percentage of minority students, many defined as "at-risk" by the Texas Education Agency. Similar pre-college introductions to engineering have been shown effective at encouraging underrepresented minorities to pursue studies in science, technology, engineering and mathematics (STEM) fields. ${ }^{x i}$ Presentations ranged from 15 minutes to one hour. All presentations were hands-on as shown in Figures 6 and 7 below. 
TABLE II

OUTREACH TO HOUSTON AREA SCHOOLS (STATISTICS AVAILABLE FROM DISTRICTS LISTED).

\begin{tabular}{|c|c|c|c|}
\hline School & $\begin{array}{c}\text { Students Served in } \\
\text { Demonstration }\end{array}$ & Underrepresented Demographic & Location \\
\hline Alief Middle School & $\begin{array}{l}30 \\
75\end{array}$ & $\begin{array}{l}\text { 49\% Hispanic, 34\% African American, } 14 \% \text { Asian, } \\
\text { 3\% White, }<1 \% \text { Native American } \\
\text { (75\% qualify for reduced price lunch) }\end{array}$ & $\begin{array}{c}\text { Rice U } \\
\text { Alief MS }\end{array}$ \\
\hline $\begin{array}{l}\text { Austin High School } \\
\text { (HISD) }\end{array}$ & $\begin{array}{l}25 \\
25 \\
40 \\
40\end{array}$ & $\begin{array}{c}\text { 96\% Hispanic, } 2 \% \text { African American, } 1 \% \text { White, } \\
<1 \% \text { Asian, }<1 \% \text { Native American } \\
\text { (78\% at-risk) }\end{array}$ & Austin HS \\
\hline $\begin{array}{l}\text { Cornelius Elementary } \\
\text { (HISD) }\end{array}$ & 45 & $\begin{array}{c}\text { 77\% Hispanic, 20\% African American, 2\% Asian, } \\
1 \% \text { White, }<1 \% \text { Native American } \\
\text { (66\% at-risk) }\end{array}$ & Rice U \\
\hline $\begin{array}{l}\text { Klein Middle School } \\
\text { (Klein) }\end{array}$ & 35 & $\begin{array}{c}\text { 45\% Hispanic, } 44 \% \text { African American, } 6 \% \text { Asian, } \\
5 \% \text { White, }<1 \% \text { Native American } \\
\text { (69\% qualify for reduced price lunch) }\end{array}$ & Rice U \\
\hline
\end{tabular}

Figure 6 shows a demonstration by Ali Hamshari and Clint Corcoran to students from Klein Middle School. This visit was arranged by the Rice Chapter of the Society of Women Engineers President Alessandra Carreon, to the top-right in the picture. During their visit, students filtered dirty water and water dyed with food coloring to learn about the capabilities of sediment and carbon filters. A demonstration with FO was also conducted. Finally, the solar SEEDPACK was presented and discussed. The students asked many insightful questions about alternative

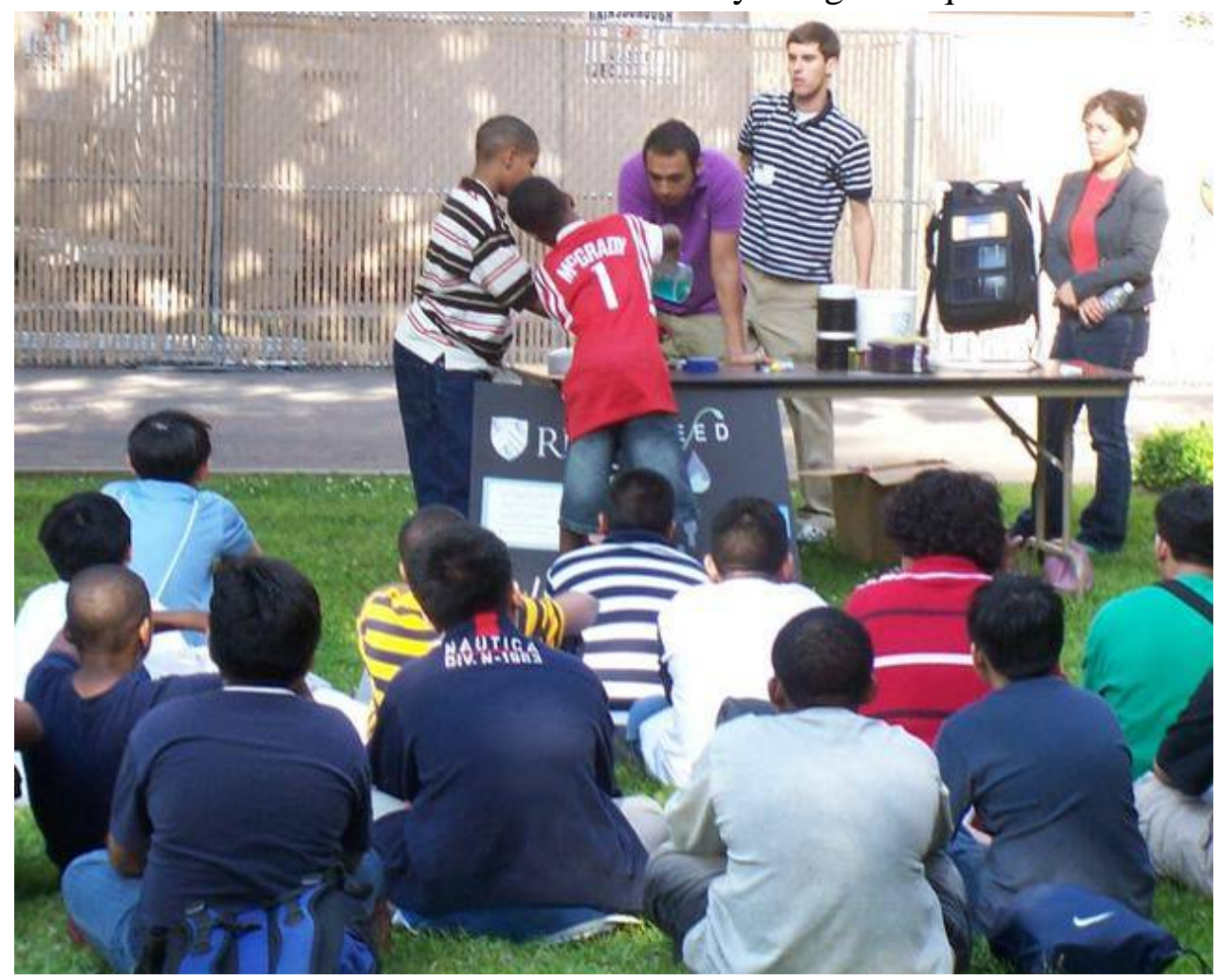

FIGURE 6

Demonstration to Klein Middle SCHOOl STUdents AT Rice University. 


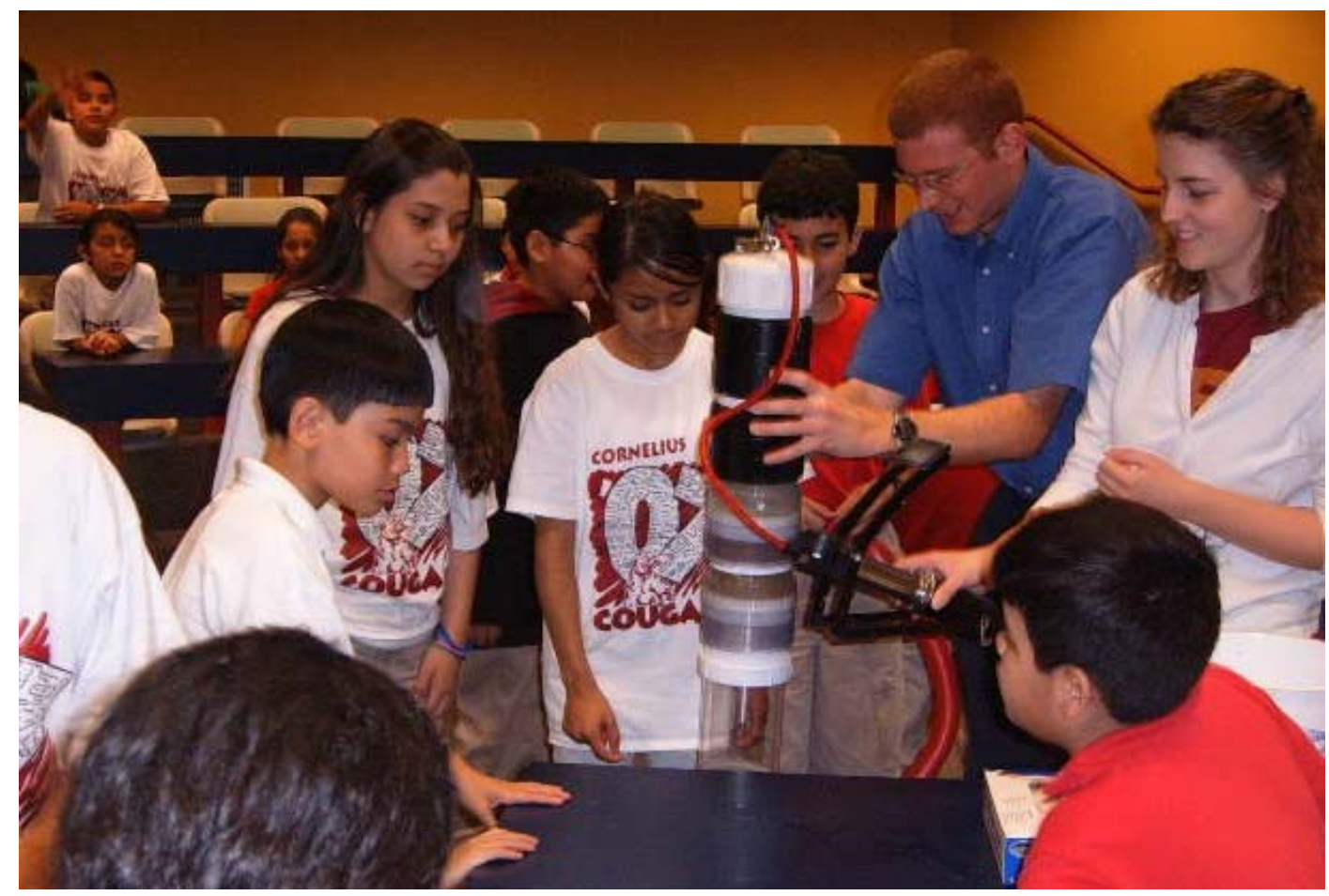

FIGURE 7

\section{DEMONSTRATION TO CORNELIUS ELEMENTARY STUDENTS AT RICE UNIVERSITY.}

energy options ranging from wind to nuclear power. Their attention was held due to the interactive nature of the Laboratory.

Jim Tuttle and Kelsey Beach are shown in Figure 7 demonstrating sediment and carbon filtration in series to students from Cornelius Elementary School. Here, a clear housing is used for the carbon filtration, allowing students to observe the removal of food coloring which is not trapped by the sediment filter in the first stage. The water exits into a clear, vented cup, and the filter housings are pressurized with a bicycle pump. As shown by the picture, the students were very interested in the demonstration and the science behind it.

\section{Broader Dissemination}

The Laboratory adheres to the six requirements found in a recent study as necessary for successful science education outreach. These include: beginning with an assessment that involves students and teachers, building partnerships, incorporating college students, making regular evaluations, securing funding and publishing results. ${ }^{\text {xxii }}$ In the coming year the SEED Foundation will evaluate the feasibility of mass producing the Laboratory and distributing it to the schools it sponsors around the world. Experimental modules have been written to guide students and teachers through possible combinations of treatment techniques, and these will be translated by SEED.

The longevity and success of this project will be measured in two ways. First, the Laboratory will continue to be used in outreach to local schools. Most notable is an ongoing mentoring program at Austin High School that pairs Rice students with high school freshmen and sophomores. The ultimate goal of this program is to attract underrepresented students to study mathematics, science and engineering. Saturday morning science fair help is one of the most 
successful components of this program, and the Laboratory could be used to inspire new science fair projects on water quality issues in the Houston area.

Second, with the help of SEED, this project will be implemented throughout schools in the developing world. SEED runs workshops to educate teachers in the schools they sponsor on the use of projects, such as the Laboratory. The educational component will then become selfsustainable, as many students can benefit from the Laboratory for years with only minimal maintenance.

\section{FUTURE WORK}

The work stimulated by this project includes research on reverse osmosis membrane fouling and a capstone design project to implement a water filtration and purification system for a SEED school (Centro Educativo Integral No 1) in Villahermosa, Mexico. For brevity, the research component is not discussed in detail here. The initial models and experimental work on the fouling mechanisms in reverse osmosis filtration are described in Hale et al. ${ }^{\text {xxii }}$ The key contributions to this ongoing research include the improved understanding of filtration processes, water quality issues and sustainability efforts and the collaborations that formed with groups such as Engineers Without Borders.

This project also provided the backbone for a grant proposal to the Environmental Protection Agency's P3: People, Prosperity and the Planet Student Design Competition for Sustainability. $^{\text {xxiv }}$ This project entails implementing a Manz biosand filter at a SEED school in Villahermosa, Mexico. ${ }^{\text {xxv,xxvi }}$ A final solar powered UV sterilization will be included, thereby providing safe drinking water to the students. The mold for the biosand filter will be donated to the community, so that the system can be used by anyone for only the minimal cost of the concrete needed to build the filter. The Laboratory will be used in a workshop at the school to educate the students about the hazards in their current water supply and promote sustainable use of the new system. The proposed work has been funded by the EPA and is currently in progress.

\section{CONCLUSIONS}

The Adaptive WaTER Laboratory successfully met or exceeded all design goals. A complete and working prototype with sediment, carbon, reverse osmosis, forward osmosis, chemical and UV treatment methods was designed and constructed. Demonstrations of the Laboratory proved it is an effective educational tool, and promotes awareness of sustainable water use. The project promoted outreach to the Houston community, and can be used by SEED to further their education for sustainability efforts in developing nations throughout the world. A future design project was conceived and a grant proposal was submitted to fund the work. Collaborations established with organizations such as Engineers Without Borders will be critical to the successful design and implementation of the proposed water treatment facility. Finally, ongoing fundamental research on reverse osmosis membrane fouling was also enhanced by this project.

\section{ACKNOWLEDGMENT}

We would like to thank Schlumberger's SEED Foundation for supporting the development of the Adaptive WaTER Laboratory and facilitating future projects to be carried out at Centro Educativo Integral No 1, Villahermosa, Mexico. We would also like to thank the Rice Engineers Without Borders Chapter for help with bacteria testing and general guidance throughout the project. 
Educational materials, plans and a parts list for the Adaptive WaTER Laboratory are available by writing to the corresponding author at houchens@rice.edu.

\footnotetext{
${ }^{\mathrm{i}}$ www.seed.slb.com , accessed May 29, 2007.

ii www.seed.slb.com/en/things_to_do/projects/ocean_of_stories/index.htm , accessed May 29, 2007.

iii www.seed.slb.com/en/about/seedlink/december2006.htm , accessed May 29, 2007.

iv Lehr, Jay H., Domestic Water Treatment. New York: McGraw-Hill, 1980.

v Svarovsky, L., ed. Solid-Liquid Separation. Boston: Butterworth-Heinemann, 2000.

${ }^{v i}$ Hassler, J., Purification with Activated Carbon. New York: Chemical Publishing Co. Inc., 1974.

vii www.sea-pack.com/lifepack.html, accessed May 29, 2007.

viii Amjad, Zahid. Reverse Osmosis: Membrane Technology, Water Chemistry, and Industrial Applications. New York: Van Nostrand Reinhold, 1993.

ix "Reverse Osmosis (RO) Water Filters." Home Water Purifiers and Filters.

http://www.home-water-purifiers-and-filters.com/reverse-osmosis-filter.php , accessed May 30, 2007.

x “Water Disinfectants.” Lenntech. 2006. accessed May 2, 2007.

http://www.lenntech.com/water-disinfection/disinfectants.htm.

${ }^{x i}$ Lykins, Jr., Benjamin W., Robert M. Clark, and James A. Goodrich. Point-of-use/Point-of-entry for Drinking Water Treatment. Chelsea: Lewis Publishers, 1992.

xii www.uvaquastar.com, accessed May 30, 2007.

xiii ewb.rice.edu , accessed April 16, 2007.

xiv www.idexx.com/water/colisure/, accessed May 30, 2007.

${ }^{\mathrm{xv}}$ Rice, E. W., Eaton, A. D. and Clesceri, L. S., ed. board, Standard Methods for the Examination of Water and Wastewater. APHA, AWWA, WEF, 2007. www.standardmethods.org/ , accessed May 29, 2007.

xvi www.htiwater.com , accessed May 30, 2007.

xvii www.steripen.com , accessed May 30, 2007.

xviii Www.alief.isd.tenet.edu , accessed May 30, 2007.

${ }^{x i x}$ www.houstonisd.org, accessed May 30, 2007.

${ }^{\mathrm{xx}}$ www.kleinisd.net, accessed May 30, 2007.

${ }^{x x i}$ Chubin, D. E., May, G. S. and Babco, E. L. Diversifying the Engineering Workforce. J. Engineering Education, 94 (1), 73-86, 2005.

${ }^{x x i i}$ Felix, D. "Creating the Quintessential Science Education Outreach Program” from the Proceedings of the Oak Ridge Center for Advanced Studies (ORCAS) Workshop on K-12 Science and Math Education, The Do’s and Don'ts: Creating a Path to Impact Science and Math Literacy, 2006.

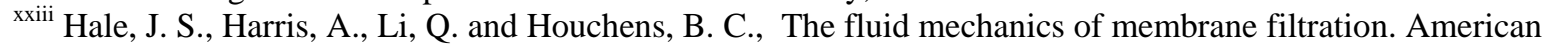
Society of Mechanical Engineering conference paper, Proceedings of the 2007 International Mechanical Engineering Congress and Exposition, Seattle, WA.

xxiv es.epa.gov/ncer/p3/, , accessed May 24, 2007.

${ }^{x x v}$ Duke, W. F., Nordin, R. N., Baker, D. and Mazumder, A., The use and performance of BioSand filters in Artibonite Valley of Haiti: A field study of 107 households. Rural and Remote Health, 6, 570, 1-19, 2006.

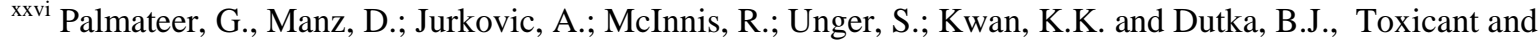
parasite challenge of Manz intermittent slow sand filter. Environmental Toxicology, 14, 217- $225,1999$.
} 